\title{
Irish Tridentine Catholicism in Victorian Toronto: Vessel for Ethno-religious Persistence
}

\section{Murray W. Nicolson}

Volume 50, numéro 2, 1983

Bilan de l'histoire religieuse au Canada

Canadian Catholic History: A survey

URI : https://id.erudit.org/iderudit/1007214ar

DOI : https://doi.org/10.7202/1007214ar

Aller au sommaire du numéro

Éditeur(s)

Les Éditions Historia Ecclesiæ Catholicæ Canadensis Inc.

ISSN

0318-6172 (imprimé)

1927-7067 (numérique)

Découvrir la revue

Citer cet article

Nicolson, M. W. (1983). Irish Tridentine Catholicism in Victorian Toronto: Vessel for Ethno-religious Persistence. Sessions d'étude - Société canadienne d'histoire de l'Église catholique, 50(2), 415-436.

https://doi.org/10.7202/1007214ar

Tous droits réservés @ Les Éditions Historia Ecclesiæ Catholicæ Canadensis Inc., 1983
Ce document est protégé par la loi sur le droit d'auteur. L'utilisation des services d'Érudit (y compris la reproduction) est assujettie à sa politique d'utilisation que vous pouvez consulter en ligne.

https://apropos.erudit.org/fr/usagers/politique-dutilisation/ 


\title{
Irish Tridentine Catholicism in Victorian Toronto: Vessel for Ethno-religious Persistence* $* *$
}

\author{
by Murray W. NicolsoN \\ Wilfrid Laurier University, Waterloo, Ont.
}

The Famine Irish immigrants rapidly increased the size of the Catholic population in Victorian Toronto. That peasantry carried with it defense mechanisms which had evolved as responses to British rule, and cultural patterns that had been socially expressed and transmitted for generations in Ireland. As foreign bearers of a rural culture in a new urban setting, the Famine Irish were under pressure to conform. When the Catholic Church organized and expanded to meet the pressing needs of that deprived group which, in absolute numbers, formed its laity, it too was considered an alien threat. Therefore, unity between the nominally Catholic Famine Irish and the Church was essential if the group and the institution were to survive in Toronto. Through the growing association between the Church and the people, a new, distinctive, ethno-religious culture developed - Irish Tridentine Catholicism.

\footnotetext{
* This paper was written in response to the apparent Marxist orientation in the growing field of what is called 'the new working-class history', and to certain aspects of an invigorated rural history. Proponents of the new working class history state that neither ethnicity nor religion can be studied outside the parameters of the new field. Regardless of whether this is feasible or not, it seems the real reason for this specific criterion is that once ethnicity and religion are contained in the new field they are ignored because they stand in the way of a unified Marxist culture. In rural history, the thrust tends to deny Irish Catholics an urban experience by stating there were no ghettos in Canada because the Irish were dominantly ruraldwellers and their adjustment was much easier than that in American cities.

However, by applying some concepts from the new American field of ethnoreligious history I have created a model for a specific Irish Catholic culture that developed in the ghettos during the Victorian age. This particularistic culture remained constant and did not disappear into a common, working class culture. Furthermore, it was transferred to the rural areas of Ontario, making an urban-rural consensus.

** Tridentine: pertaining to the Council of Trent, or conforming to its decrees or doctrines.
} 
The new culture was an uniform vehicle because group cohesion prevented the strictures of class from weakening its application. Embodied in it were the best elements of the peasant past, reflected through new urban responses that made life in the unfriendly city more bearable. Initiating in the Irish ghetto of Toronto where peasants encountered the personnel of their Church, it expanded with growing parish networks and was diffused throughout Toronto. The community was strengthened by a sense of the "Irish Holy" and commissioned with an "Irish New World Millenium" that produced a "Dearcadh", a distinctive outlook. Although it was hidden behind a form of group-oriented, ethno-religious privatism, it became the standard working-class culture of Irish Catholics in the new world Irish diaspora. From Toronto, as the archiepiscopal city and the centre of Irish culture, it spread by way of the Church's metropolitan communication network, Irish newspapers, kinship patterns and societies to the rest of English-speaking Catholic Ontario.

Some American historians have attributed religion as a salient factor on the adaption and retention of particularistic cultures. Randall M. Millar and Thomas D. Marzick observed:

...immigrants turned to religion, the very bone and sinew of ethnicity, to shore up communal ties... In their families and in their religion they sought comfort and relief from employers and those who would have them give up their identity as Czecks, Poles, Germans, Jews, Irish. ${ }^{1}$

However, the role that religion played in the retention and reinterpretation of culture in Canada has not as yet been recognized, far less defined. This neglect has restricted an understanding of immigrants in the Canadian milieu.

There are a number of apparent reasons which might explain why religion has not been considered as a criterion in the study of Canadian ethnic groups. One major factor could be the application of the 'Folk Urban Continuum', ${ }^{2}$ a theory which implies that all immigrant groups, following a period of adjustment, assimilate and form a section of the charter group culture. Utilizing that context, it follows that Catholic

\footnotetext{
'Randall M. Miller, "Introduction", Randal M. Miller and Thomas Marzik, eds., Immigrants and Religion in Urban America, Philadelphia, 1977, pp. XIV, XV.

2 Robert Redfield, "The Folk Society", The American Journal of Sociology, L 11, 4, 1947, pp. 306-8.
} 
ethnics rapidly formed a religious subculture with little ethnic diversity. Furthermore, in a persistent attempt to conceptualize a unified workingclass, the new labour historians, by virtue of Marxist orientation, abandon religion and ethnicity to ensure the working-class culture they describe has the patent appearance of uniformity. ${ }^{3}$ Recently, this new working-class history has been attacked by David Bercuson who believes religion is ignored "because of what its analysis might reveal about the lack of cultural unity among the working-class. ${ }_{4}$

Perhaps another reason for neglecting religion as a social criterion is the poor definition of ethnicity. Timothy L. Smith observed: "Historians continue to believe that ethnicity is a synonym for nationality and that the religious and ethnic sentiments of immigrant minorities are anachronisms that give way to the process of modernization and assimilation." 5 Difficulties were encountered when the Irish were studied as a single, ethnic group because their religious differences distorted any unified approach. As a result, religion was separated from Irish social or cultural life, or subdued or abandoned as a central criterion. ${ }^{6}$ There can be little doubt "that religion and ethnicity are intertwined in modern urban and industrial societies" 7 and, most certainly, that duality could not be avoided in the nineteenth century.

The Irish Catholic immigrants who entered Toronto in the early decades of the nineteenth century showed signs of what has been called the 'Folk Urban Continuum'. Between 1805 and 1834, their population grew from 6 to 3500 in the entire Mission of York which included a good proportion of the Home District. ${ }^{8}$ In Toronto, the small population lived along the waterfront, in old or lower Cabbagetown, on the Don flats and in the liberties surrounding the city. Although the old Irish peasant culture survived on the Don flats, the urban dwellers

\footnotetext{
${ }^{3}$ Gregory Kealey and Peter Warrian, eds., Essays in Canadian Working Class History, Toronto, 1976, pp. 7-8.

${ }^{4}$ David Bercuson, "Through the Looking Glass of Culture: An Essay on the New Labour History and Working Class Culture in Recent Canadian Historical Writing", Labour / Le Travailleur, (Spring 1981), pp. 103-4.

${ }^{5}$ Timothy L. Smith, "Religion and Ethnicity in America". The American Historical Review, vol. 83, no. 5 (December 1968), p. 1155.

${ }^{6}$ For a unitary study of the Irish, see: D.S. Cross, "The Irish in Montreal 1867. $1896^{\circ}$, M.A. Thesis, McGill University, 1969.

${ }^{7}$ Smith, "Religion and Ethnicity", p. 1155.

${ }^{8}$ Archdiocese of Toronto Archives (hereafter ATA), Macdonell Papers, Early Church Census.
} 
were a fast-assimilating group, accepting the cultural standards of the charter population. Intermittently, they were led by a non-Irish elite, Catholic members of the Family Compact who did not adhere strictly to the laws of the Church but, rather, married before more socially acceptable Anglican ministers, raised some children Anglican, and joined the Masonic Order. ${ }^{9}$ The Irish Catholics belonged to forbidden societies and celebrated a secular St. Patrick's Day with their fellow countrymen. They had few leaders of their own nationality and, in most cases, those were the editors of the city's Irish newspapers. By following them, the Irish were involved in radical politics which divided the community and set them at odds with their Tory Bishop, Alexander Macdonell. But generally, the Irish were tolerated by the population of Toronto, for it was expected they would eventually be absorbed through assimilation. ${ }^{10}$

In that early period, the Catholic Church was not an urban actor. Bishop Macdonell, a great mission prelate, believed the future of his Church lay in close association with the Tory establishment of which he was a member. Convinced that the Rideau Canal would make Kingston the commercial metropolis of Upper Canada, he chose it as his See. And in that mistaken analysis, York was left a neglected mission. It was not until 1822 that the Catholic population acquired its first Church, St. Paul's, and it had no resident priest until 1828. There were no schools, no institutions, no orders of priests or nuns. As well, the administration of St. Paul's Church was delegated to lay vicars, a contentious act in the view of the Irish who resented the Compact monopoly of power in their church. ${ }^{11}$

Initially, Bishop Macdonell felt secure in the appointment of Father William O'Grady to St. Paul's. But O'Grady's rise as an ethnic leader and his involvement in reform politics drove a wedge between the Toronto Irish and their Church. Because of inappropriate, overt actions on the part of O'Grady and his followers, Macdonell placed St. Paul's Church under interdict and O'Grady and other Irish leaders were excommunicated. Although Macdonell is credited with keeping the Irish Catholics out of the Rebellion of Upper Canada, the ex-priest O'Grady,

\footnotetext{
${ }^{9}$ As yet little has been written on this elite group. For some evidence see: ATA, Macdonell Papers; and the unpublished manuscript, Murray W. Nicolson, "Identity and Function of the Catholic Compact in Early Toronto".

${ }^{10}$ See the issues of the first Canadian Freeman, 1828-33.

${ }^{11}$ ATA, Macdonell Papers; the Bishop's correspondence shows both his preference for the eastern portion of Upper Canada and the lack of institutional formation.
} 
was instrumental. And when it was over, the Catholic community of Toronto was still torn with dissension between the old Compact elite and the Irish led by another priest, Father Patrick McDonough. ${ }^{12}$

It was not until the Diocese of Toronto was established under the jurisdiction of Bishop Michael Power that some stability occurred, even though Power's tenure was short. With the decline of a power-base among the old elite, Bishop Power began to build a diocesan organization to replace the mission church Macdonell had administered. To exercise more control over what had become an unsupervised, independent minded clergy, Power divided his Diocese into deaneries and instituted the synod. He concentrated his efforts on the external signs of episcopal presence by building St. Michael's Cathedral and the Bishop's Palace. However, his acceptance of the Chairmanship of the Board of Education of Upper Canada stamped episcopal sanction on an educational system that was to become the vehicle for conformity to the charter group's concept of culture in the city and the province. ${ }^{13}$

The arrival of the Famine Irish in 1847 changed Protestant Toronto, for it was burdened with the problems of a disease-ridden peasant population whose mores differed completely from those of the charter population. While the city hid in fear of the contagion the Irish brought, Bishop Power called the available priests from his Diocese and with them and the layman, John Elmsley, nursed the sick immigrants in fever sheds set up on the wharves. Power succumbed as a consequence of that ministry and gave the Irish an ethnic martyr in their new homeland. ${ }^{14}$ Knowing that a Bishop had died giving them assistance and priests and a former Compact layman tended them when others would not, the Irish Catholic immigrants paid little heed to the Protestant admonition: "In the name of common sense abandon such damnable, forbidden and unscriptural worship." 15 Instead, the city's lack of concern and the growing signs of the populace's hatred towards them fostered the creation of a cohesive relationship between the nominally Catholic Irish and their traditional focus, the Church.

\footnotetext{
${ }^{12}$ ATA, Macdonell Papers provide some documentation on the career of William John O'Grady; Unpublished manuscript, Nicolson, "William John O'Grady, Rebel Priest".

${ }^{13}$ ATA, Power Papers give evidence of Bishop Power's goals and accomplishment and describe his philosophy of education.

${ }^{14}$ E. Kelly, ed., The Story of St. Paul's Parish Toronto, Toronto, 1922, pp. 84-104.

${ }^{15}$ ATA, Power Papers, A Christian to Rev. Carl (Carroll), no date.
} 
During the period of interregnum from the death of Bishop Power to the arrival of Bishop Armand de Charbonnel in 1850, the work of the Church came to a virtual halt. Without the operational structure of a hierarchical form of government, a number of the all-too-few priests in the Diocesan hinterland fell back on old Gallican customs, convinced they had autonomous rights in their own parishes and were beyond the control of any bishop. Actually, there were no traditional parishes in Upper Canada - just constituted missions. The system of deaneries and the yearly synod had fallen into abeyance and those undisciplined priests gathered a considerable amount of independent power and wealth. The Cathedral and Bishop's Palace were encumbered with dept. And in the city there was a very small group of the Sisters of Loretto who had immigrated as Bishop Power died. ${ }^{16}$ Meanwhile the poor, starving Irish immigrants were left at the mercy of the city's overburdened charitable institutions which offered assistance in return for conversion, a tactic to which they had been exposed in Ireland. Blatant souperism had begun in 1846-47 on the wharves of Quebec and Montreal with the Protestant cry: "a bowl of soup if ye'll turn". ${ }^{17}$ It was to continue almost until the turn of the century.

With the arrival of Bishop Charbonnel, however, change was a sine qua non. Charbonnel, educated by the Basilians, was a former French Count, the nephew of Cardinal Charbonnel of Puy. He was a Sulpician monk who had been a professor of dogma at Lyons. Stationed in Montreal when the Famine Irish immigrants arrived, he contracted typhus while working among them and returned to France to recuperate. Subsequently, he was consecrated Bishop of Toronto by Giovanni Maria Mastai-Ferretti, Pio None, the brilliant administrator whose style Charbonnel adopted. Under Charbonnel's tenure, the Church in Toronto advanced from a mission entity to a sound metropolitan institution. Through his actions, the Famine Irish immigrants were remoulded in a Catholic image, an ethno-religious thrust that was strengthened by Charbonnel's chosen successor, John Joseph Lynch. ${ }^{18}$

\footnotetext{
${ }^{16}$ ATA, Power Papers include the lists of institutions and the priests' correspondence during the period of interregnum after Power's death.

17 John McGonigal, "All the Big Irishmen are in the Ottawa Valley", Joan Finnigan, ed., Some of the Stories I Told You Were True, Ottawa, 1981, p. 44.

${ }^{18}$ See in general : R.P.C. Cause, Évêque D'Or, Crosse De Bois: Vie De Monseigneur De Charbonnel, Évêque De Toronto, Paris, 1930.
} 
Charbonnel evaluated the needs of his laity and immediately began to re-organize the weak Church and to establish institutions. To gain control over the Gallican-minded clergy, Charbonnel revitalized the system of rural deaneries and priests synods and set up church tribunals. To eradicate the debt of the Cathedral, he established the Cathedral Loan Fund, introduced the Dime, or Cathedraticum, and demanded strict fiscal accountability. The laity in the interland area was called upon to shelter Irish Catholic orphans and to supply food. Charbonnel set the example of Christian poverty and charity; his clothing was tattered, his diet not much better than that of the common Irish peasantry he served. And he gave his family fortune to the Diocese of Toronto. ${ }^{19}$

To bring about social change for his deprived laity and to develop the internal linkage essential to an ecclesiastical metropolitan system, Charbonnel utilized the external communication system of the universal Church. Having been raised in France in a period when the institutional Church withnessed the growth of Catholic social action and a renewed devotionalism, Charbonnel looked to his mother country to provide personnel and models to assist him in his task. He chose the Basilian Fathers to train priests, the Christian Brothers to teach in the schools, and the versatile semi-cloistered Sisters of St. Joseph to care for the numerous orphans and to complement the teaching work of the Sisters of Loretto. In addition, he encouraged the old Catholic elite to establish the St. Vincent de Paul Society to provide aid to the poor. Those steps, taken within the first two years of Charbonnel's episcopacy, were a prelude to the creation of a new, Irish urban identity. The religious and lay organizations drew membership from the Irish community they were commissioned to serve and, with an emerging Irish press, became elements in a communication system that refined the various components in a new culture and transferred it to the people in the city and the hinterland. ${ }^{20}$

The pre-Famine Irish did not disturb the Protestant consensus of the city, for with few priests and no institutions they posed little threat. However, after the arrival of the Famine Irish, that alien population grew from an estimated 2000 in the city to 7940 , or 25.8 per cent of Toronto's population in 1851 , and climbed to 12,135 , or 27.1 per cent by $1861 .{ }^{21}$ Their presence could no longer be ignored; they were a

\footnotetext{
${ }^{19}$ Ibid; ATA, Charbonnel Papers; and the Records of the St. Vincent de Paul Society.

${ }^{20}$ Ibid.

${ }^{21}$ Canada, Board of Registrations and Statistics, Census of the Canadas 1851-52, 1, pp. 30-31, 66-67; and for 1860-611, p. 48.
} 
formidable minority. The Protestant majority alarmingly viewed the concurrent development of Catholic institutions to serve the Irish laity as signs of a strong Papal conspiracy. The sudden and continued burst of activity with the construction of new churches, rectories, halls, schools, orphanages, The House of Providence, hostels for girls, apprentices and newsboys, the work of the St. Vincent de Paul Society, the religious orders and women's groups, and, towards the end of the century, the establishment of St. Michael's Hospital and the Catholic Children's Aid Society did little to allay Protestant fears. What the Protestant population failed to perceive was that Catholic institutions in the city grew in proportion to the inequity, intolerance, souperism and ill treatment Irish Catholic immigrants experienced in public institutions. The separate schools, particularly, were demanded to end proselytism, to guarantee religious rights constitutionally, and to provide security from ridicule and overt acts of violence, like stoning, to which the children, the priests, the sisters and the Bishop were subjected in the streets of Toronto. ${ }^{22}$

The Catholic peasants who migrated to Toronto after the Famine came primarily from the west of Ireland. Because of their poverty, they crowded into the old areas of Irish concentration in Cabbagetown, along the Don flats and to the liberties where they were exempt from taxes, enlarging or creating commonly known Slab, Cork or Paddy towns. Population growth pushed them to the west to form Clairetown in what had been the old Garrison Reserve, and north into St. Patrick's Ward. Uneducated and unskilled, those Irish peasants were transients and became urban and inter-urban nomads in their search for work. They followed industrial and railway development because it was cheap to reside close to the source of employment. By 1900 the Irish Catholics were scattered throughout the city in a dozen small pockets, but were concentrated in four major areas: Cabbagetown; the waterfront; Clairetown; and in the Junction at the extreme west end. ${ }^{23}$ The Church followed the Irish throughout the city, establishing parish nuclei to serve them. In just two instances the Church preceded the advance of the Irish : St. Michael's Cathedral and St. Basil's Church. ${ }^{24}$

\footnotetext{
${ }^{22}$ Nicolson, "Irish Catholic Social Action in Toronto, 1850-1900". Studies in History and Politics, vol. 1, no. 1, 1980, pp. 29-55.

${ }^{23}$ Sadlier's Catholic Almanac and Ordo, New York, 1864-80; and ATA, Registers of Births, Marriages and Deaths.

${ }^{24}$ Ibid.
} 
The Irish immigrants were the bearers of an old peasant culture adapted to include many defence mechanisms developed as responses to harsh English rule in Ireland. And with considerable difficulty the Irish had made various attempts to preserve that rural culture. But, their language was dying out; many, old regional and kinship patterns had been shattered; their voluntarism and organizational ability was in decline and what was left was wasted in secret societies which produced faction fighting and quarrels with the Orange Order. Having been detached from their religion, their folk customs were more pagan than Christian, their behaviour and standards unacceptable to the charter population. ${ }^{25}$

As things stood in 1850 , Irish culture as a rural vehicle needed some reinterpretation if it was to survive in any recognizable form in the urban setting. Conversely, the Church needed the support of the Irish immigrants to make it a viable institution. Bishop Charbonnel concluded that he had to build a bridge between the institution and the ethnic group, or lose both, and identified Irish religion with Irish nationalism. Over a protracted period, the interaction produced a selective process wherein a peasant culture and catholic Tridentinism merged to form a new, urban, cultural vehicle. In that process, many elements of Irish culture had to be replaced, moderated or reinterpreted. At the same time, certain basic, traditional values had to be strengthened and new religious practices introduced that were culturally adapted to Irish needs. In a sense, traditional Catholicism was coloured green.

One problem that confronted the Church was the lack of conformity in Irish marriage practices because, in most cases, the technicalities surrounding canon law were beyond their comprehension. The Decree Tamesti of the Council of Trent created confusion over what constituted a valid or an invalid marriage. Because Canada was a mission territory, the Decree did not apply and, therefore, marriage between Catholic partners officiated by a Protestant clergyman was considered valid. However, at the first opportunity following the Protestant or civil ceremony, couples were compelled to renew their vows before a Catholic priest and to make promises regarding the children. Even when sufficient priests were available many Irish persisted in the former, more convenient practice of marriage before Protestant ministers, claiming ignorance of Church law. In some instances, it was to escape the impediments of consanguinity or affinity between partners; in others, to avoid the cen-

\footnotetext{
${ }^{25} \mathrm{~K}$. Duncan, "Irish Famine Immigration and the Social Structure of Canada West", Canadian Review' of Sociology and Anthropology', 2:1, 1965, pp. 19-40.
} 
sure of mixed marriage where partners agreed to raise the children in different religions. Because of poverty, a number of widows and deserted women became common-law wives in order to survive and to raise their children. Many couples had been married in Ireland by simple, hand-first unions, exchanging their vows before witnesses, without the benefit of a priest. Overall, those arrangements contributed to instability and, consequently, were responsible for concubinage, abandonment and substantial numbers being lost to the faith. ${ }^{26}$

The corrective process began before the arrival of the Famine immigrants when Bishop Power declared that all marriages had to be celebrated in a church. Concerned with the amount of seepage that was occuring, Charbonnel introduced more stern control measures. All mixed marriages were to be performed before a priest, without any solemnity, but with the promise of baptism and Catholic education guaranteed to the children of the union. He insisted that the Diocesan priests submit reports on the number of dispensations granted for mixed marriages and provide continued evaluations on the religious condition of the partners and children involved. As an added protective measure to guard against seepage, the Vatican limited the number of dispensations. Eventually, the Irish community exercised societal control by censuring those who disregarded the laws of the Church concerning marriage practices. Although it was not until 1907, with the Decree Ne Temere, that problems regarding marriage were resolved, it can be stated that the Church gained control over Irish marriage customs during the espiscopate of Charbonnel. ${ }^{27}$

Closely related to the marriage customs and the unacceptable moral standards of the Irish laity was the number of illegitimate births in the city. The decline in the illegitimate birth rate demonstrates clearly the penetration of Catholic moral philosophy into the culture of the Irish group. In 1858 the illegitimate birth rate was 9.53 per cent and dropped to 2.94 per cent by $1898 .{ }^{28}$ Generally, records show that the infant mortality rate was high, not an unexpected statistic when one considers the poor conditions in which the Irish existed. One suspicious observation was the number of deaths occurring shortly after the birth of sickly, deformed children. That might preclude the continuance of the Irish practice of either destroying or neglecting imperfect children believed

\footnotetext{
${ }^{26}$ ATA, Power Papers and Charbonnel Papers, correspondence and pastorals.

${ }^{27}$ Ibid.

${ }^{28}$ ATA, Parish Records of Births.
} 
to be changelings, left by the Sidhe, or fairy, in place of a healthy child. Many of the infants who died were buried in the garden patches of Cabbagetown. Although there is little manuscript evidence about the belief in changelings, it was common in Ireland and supported by oral history in Ontario. Improved diet and sanitation contributed to a better form of prenatal care in the physical realm. That, combined with the fact the Church gained control over marriages of consanguinity, implemented a program of moral teaching and provided institutions to care for abandoned infants, helped to reduce the number of children in that category. One must emphasize that infanticide was not intentional, but just a method, rationalized by Irish folk belief, to reduce the number of hungry mouths to be fed where survival was tenuous at any rate. ${ }^{29}$

The make the Irish more acceptable in the urban milieu, the Church had to moderate some of the responses that had become an integral part of Irish culture under British rule. Drunkenness and alcoholism were endemic, almost genetic, among the Irish. In rural Ireland, drinking served as an escape from an harsh environment; in Toronto, as in other urban centres, it contributed to a number of related social problems and was attached closely to the Shebeen Society. Within that society, Irish males gathered to discuss politics, plan ethnic strategy and mete out vengence against those of the Irish community who had broken customary laws, or against Orangemen who had been abusive. ${ }^{30}$

Through the schools and from the pulpit, especially during the Mission, the Church preached temperance. Sobriety was a prerequisite for membership in Irish Catholic benevolent organizations. And with the growth of temperance societies there followed a reduction in the amount of alcoholism and the extreme form of drinking that had been associated with wild weddings and wakes. The Shebeen Society had served its purpose and, although the Church influenced the drinking habits of the Irish to some extent, public hotels were commonly utilized by the Irish who still enjoyed their poteen. ${ }^{31}$ Too, in 1850, Bishop Charbonnel condemned the rowdy, disruptive and destructive custom of the Shivaree. The Shivaree, borrowed from French Canadian culture, had been adopted by the Irish in the Diocese of Toronto as a drunken, housewarming

\footnotetext{
${ }^{29}$ ATA, St. Paul's and St. Michael's Cemetery Records, 1850-60.

${ }^{30}$ ATA, Charbonnel Papers, and Lynch Papers provide temperance related material; and the Records of the St. Vincent de Paul Society.

${ }^{31}$ Ibid.
} 
reception for newly married couples, or as a show of distaste for what the Irish community considered an unsuitable match. Vestiges of that adaptation and the term 'shivaree' are still used in York County today. ${ }^{32}$

The Irish loved to dance and had introduced jigs and reels to Canada. But dancing was an activity that disturbed Church authorities who considered it a source of immorality, particularly among the youth. Charbonnel denied the sacraments for a whole year to those who participated in what he called lascivious dances, prohibited by the Sixth Commandment as an immediate occasion of mortal sin. ${ }^{33}$ Bishop Lynch labelled the popular lascivious dances revived in Germany, "Polkas, Masirkas, Waltzes and vulgarly they are called fast dances, hugging dances" as dangerous to purity because their positions of close contact favoured sensuality which would result in sin. ${ }^{34}$ The Church had to reach a compromise because dancing was entrenched in Irish culture. Chaperoned dances were tolerated and permitted as a source of revenue for charitable ventures; the religious orders could take no part in them but the Irish retained dancing as a favourite form of entertainment. ${ }^{35}$

Perhaps the wake and funeral practices were aspects of Irish culture that created the greatest source of embarrassment to the Church in Toronto. The wake, the actual celebration of the final rite of passage, was a superstitious, pagan institution that had little to do with Catholicism. In an apparent fear of the dead, mourners attended the festivities planned to honour and entertain the corpse. Hired keeners, feasting, drinking, dancing, fighting and lewd games were accepted as the norm by the Irish, but looked upon with disgust by urban society and as unholy by the Church. If two funeral processions met at the cemetery, a fight broke out, for it was believed that the last body interred would roam the graveyard to watch over the dead until the next commital. If a corpse was denied burial in consecrated ground, Irish relatives removed the body from the grave by night and transferred it to sacred ground, often erecting a tombstone in memory. ${ }^{36}$

\footnotetext{
${ }^{33}$ ATA, Charbonnel Papers, Circular for Holy Thursday, 1856.

${ }^{32}$ ATA, Charbonnel Papers. See particularly: W.R. Riddell, "The Shivaree and the Original", Ontario Historical Society Papers and Records, vol. 27, 1927, pp. 522-24.

${ }^{34}$ ATA, Lynch Papers, Draft for a Circular, undated.

${ }^{35}$ ATA, Lynch Papers contain numerous letters about the evils of dancing and the problems the laity encountered when dances were planned.

${ }^{36}$ ATA, Charbonnel Papers and Lynch Papers, Pastorals on funerals and monuments.
} 
Through the members of the St. Vincent de Paul who visited the homes of the deceased, the Church succeeded in modifying the pagan aspects of the wake, introducing a religious and more respectable atmosphere. The requirement of having funerals take place in the church, rather than just a simple graveside commital, gave the Church more control and the overt paganism attached to that final rite of passage was reduced. Nonetheless, the death rate in the Irish community was high and that prompted the rise of Irish funeral directors who encouraged practices most families could ill-afford. Glass hearses pulled by plumed horses, the rental of mourning clothes and the erection of costly monuments, all the mode in the Victorian era, were expenses the Church considered unnecessary and wasteful. Through the efforts of the Bona Mors Society whose objective was to spread the concept that a good life assured a good death, the pastoral letters of the Bishop and the growing leadership role of the priests, Irish burial practices were influenced. They became more Catholic with an emphasis on simplicity, economy and charity, ${ }^{37}$ but the Irish term 'wake' is still part of Eastern Canadian vocabulary.

Association through societies was an important feature in Irish life. Denied any recourse to the law in Ireland, the Irish peasantry formed secret societies to dispense extra-legal, judicial decisions. That format, transferred to Canada, limited ethno-religious solidarity. What occurred in Upper Canada was the deveiopment of a number of secret societies, based upon Irish regional identities, which contributed to faction fighting. In the face of Orange pressure, secret societies in Toronto organized to form the Irish Brotherhood which operated from the Shebeen Society and the Don flats and offered protection to those of their ilk. Within the growing, post-Famine Irish population of Toronto, Irish nationalism was the focus for association through societies, a factor which placed the Church in a precarious position with governmental authorities. It seems the Irish Brotherhood was absorbed by the Hibernians, a front for the Fenians, who tried to involve the Church in Britain's quarrels in Ireland, an involvement the Church had to avoid to protect its laity in Toronto. To counteract the independent power of those vigilante and nationalistic societies, the Church founded ethno-religious benevolent organizations. As the cause of the Fenian Brotherhood dissipated with

\footnotetext{
${ }^{37}$ ATA, Records of the Bona Mors Society.
} 
improved conditions in Ireland, the Church in Toronto was left in direct or indirect control of all fraternal Irish societies. ${ }^{38}$

To protect the new but fragile culture and the rights of its predominantly working class laity, the Church had to find some way to ease the entrance of Catholic workers into unions, must of which were banned as secret, oath-bound societies based on a anti-Catholic philosophy. In defiance of Cardinal E. Taschereau, Archbishop Lynch supported the Knights of Labor whose constitution and rituals met with his approval. That was the first opportunity for Irish working men in Toronto to seek equity in the workplace. The organizational ability of Irish Catholics assisted the cause of unionism, but in that secular realm Irish Catholics maintained a separate cultural identity. They never fused with the Protestant labourers in a common, working class culture. ${ }^{39}$

The Irish tended to react violenty to situations and that feature associated with slum-dwelling, poverty, transiency and drunkenness pre-disposed them to crime. Criminal activity among the Irish could be looked upon as a salient, though ambiguous, segment of their cultural apparatus that created an inability to conform to the accepted set of legal mores in the various areas they had settled. Driven from their land by the English, owning nothing, and having no legal status as human beings in Ireland, to them the law, judge and jurors were Protestant, and evasion of the law was a duty for God-fearing Catholics. Whether emphasis is placed on cultural retention or an inability to adapt in a new milieu, the apparent disorganization that produced crime was a problem with the Irish wherever they lived. ${ }^{40}$ In Toronto, Irish Catholics were the largest group charged and convicted for crimes, even though they were in a minority position. In their case, the charges were laid because the Orange-controlled police force arrested Catholics for vagrancy, violence or drunkenness while Protestant offenders might be let off with a warning; and Orange judges arbitrarily passed sentences

\footnotetext{
${ }^{38}$ ATA, Lynch Papers contain correspondence which describes various attempts made by the Church to gain control of Irish societies.

${ }^{39}$ Nicolson, "Six Days Shalt Thou Labour: The Church and the Irish Worker in Victorian Toronto", paper given at CHA Conference, Vancouver 1983.

${ }^{40}$ ATA, Charbonnel Papers and Lynch Papers, Pastorals and sermon literature on Christian Forebearance.
} 
on those from certain street addresses within an Irish district. ${ }^{41}$ Because of the high crime statistics and the lack of opportunity for Irish Catholics in Toronto, Archbishop Lynch attempted to impede the flow of immigrants. He wrote a pastoral on "The Evils of Wholesale and Improvident Emigration from Ireland" which he intended for the eyes of bishops in Ireland only. However, it became widely publicized and Catholics attacked Lynch for his callous attitude. On-the-other-hand, Lynch's concern for the quality of life, and not necessarily for Catholic quantity, may have advanced his cause with provincial government officials. They co-operated with him to advance the position of separate schools, the fountain of Irish Catholic culture. ${ }^{42}$

It was through a wide network of social programmes that the Church improved conditions among the Irish. The St. Vincent de Paul Society and the Sisters of St. Joseph, particularly, set up a system of outdoor relief to provide food, clothing and shelter. Because of their close interaction in the homes of the poor as friends, not as social observers, they gained the trust of the Irish and set examples of Christian charity. They visited the jails and established institutions for rehabilitation, often finding employment for prisoners. The Church played a role as urban actor. Christian forebearance became the acceptable answer to insult and gradually violence subsided. The people were taught the importance of good personal hygiene and sanitary measures, and with improvement in living standards the death rate declined. That stabilized the family unit, because there were fewer widows left to raise boys who ran wild as 'Street Arabs' and frequently turned to crime, or girls who turned to prostitution to survive. ${ }^{43}$

The Church utilized a number of positive traits in the Irish cultural apparatus to improve the position of the group in the urban setting. Voluntarism, a gemeinschaft function, had been a focus for community and religious projects in Ireland. That positive element was used to advantage by Bishop Power in building St. Michael's Cathedral when the Irish provided bricks, lumber, carts, horses, labour and what little money they could afford. St. Michael's Cathedral is the single,

\footnotetext{
${ }^{41}$ City of Toronto Archives, Statistical Report of Crimes Committed in the City of Toronto, 1850-1900; ATA, Lynch Papers, The Evils of Wholesale and Improvident Emigration from Ireland.

42 Ihid.

${ }^{43}$ ATA, Records of the St. Vincent de Paul Society.
} 
surviving example of church architecture in Toronto designed by the English architect, William Thomas. Thomas, buried in Toronto's St. James Anglican Cathedral Church Yard, has been designated a Protestant by historians, However, like the Catholic laity he supervised, he donated a proportion of the cost of the roofing for St. Michael's Cathedral, "as being a member of that Church." 44 More importantly, under Thomas' direction the Irish learned building trades, skills which outfitted them to accommodate the burst of Catholic institution building that followed the Famine immigration and the rebuilding of Toronto after the great fire in 1849. From those beginnings there developed selective employment opportunities within the closeknit Irish Catholic community, and that allowed for some social mobility through the formation of a middle sector. ${ }^{45}$

That same voluntarism was a key to Irish group survival and the spread of the new, urban-born cultural identity, for it was the basis upon which the ethno-religious organizations relied. The St. Vincent de Paul Society, originally composed of old, elite Catholics, was soon to become an Irish working class society whose members served the Church as advocates of their faith. It never neglected its primary goal of providing the basic human needs, but expanded its services to furnish tools for workers, find jobs, establish an employment agency and fuel co-operative, set up libraries, work with orphans, act as truant officers, teach in night schools, found the Toronto Savings Bank under the patronage of Bishop Charbonnel - all measures intended to direct the Irish towards means of self-help within the urban community. Although assistance was offered to those of any creed, the members of the St. Vincent de Paul Society encouraged the dual identity of Catholic and Irish by spreading culture and religious attachment among their own. ${ }^{46}$

Female cognate organizations, in which the Catholic Women's League had its origins, operated in a similar manner. In fact, Catholic women organized first during the interregnum when they were disturbed by what was happening to Irish Catholic infants in the House of Industry.

\footnotetext{
${ }^{44}$ ATA. St. Michael's Cathedral Papers, William Thomas to The Building Committee of the Catholic Cathedral Toronto, 5 June 1845.

${ }^{45}$ ATA, See the papers related to the fabric of St. Michael's Cathedral and subsequent church buildings.

${ }^{46}$ ATA, Records of the St. Vincent de Paul Society; the Sisters of St. Joseph Archives, Toronto, The Annals of the Sisters of St. Joseph; and Toronto's Irish Catholic newspapers for the period 1860-80, particularly the Canadian Freeman and the Irish Canadian.
} 
To protect the religious rights of those children, an orphanage was established with was subsequently taken over by the Sisters of St. Joseph. The different women's organizations did various tasks: school children were given food and provided with clothing and shoes to protect them against the inclement weather; the sick were visited in the homes where good personal hygiene and catechism were taught; female prisoners and hospital patients were furnished with religious articles and necessary items, most handmade. Parish-oriented women's associations organized picnics, bazaars, soirees and concerts to supply funds for the operation of the institutions run by the religious orders. ${ }^{47}$ In that way voluntarism supported the independent Irish Catholic community within the broader, Protestant, secular and alien city.

The Famine had disrupted the close kinship patterns common in Ireland. The Church recognized the value of that social unit as being vital to its survival in the new, urban environment, for kinship patterns were an adjunct of the metropolitan communication system and were to become significant in spreading Irish religiosity and the new, urban culture throughout Upper Canada. Through tight-knit kinship patterns, families were drawn together for the important rites of passage. As the Church gained control over the rites, the straying Irish were brought back to the Church. Like the old regional systems in Ireland, family and kinship ties were contributing factors to a parish-oriented laity where group censure demanded conformity. The parish nuclei provided the Irish from the cradle to the grave with most of the social, religious, educational and emotional needs; within those confines they were secure and could interact at all levels - formal and informal. They served the group, and through them the Church was kept well advised of potential problems that existed within Ontario's Irish Catholic community. ${ }^{48}$

That process of making Catholics out of the Irish required considerable planning and effort on the part of Church officials. Charbonnel was appalled at the complete ignorance of the Irish laity. Within the separate schools, children were given a religious education and prepared for first communion and confirmation by the French priests. They were taught to fetch the priest in cases of illness and death. The manner in which the children were treated and the sight

\footnotetext{
${ }^{47}$ Ibid.

${ }^{48}$ The Mission Book of the Redemptorist Fathers, New York, 1897.
} 
of the priest with the Host, going into some of the worst areas of the city, often in the face of physical and verbal abuse, filled the Irish with respect. And through simple sermons, the adult Irish attracted into the Church were educated in their religion. Tracts were printed in which vast volumes of Church dogma, creed and catechism were reduced to a few, easily understood pages. Lists were compiled to explain the meaning of the external signs, like the use of candles, statues, vestments, holy water and Latin, which the Protestants viewed as superstitious symbols and practices. Of special significance in the renewal of faith was the mission or retreat introduced by Charbonnel. Eventually parish missions became the mainstay of a truly religious element in Irish culture. Societal control made attendance normal; non-attendance was considered a virtual denial of religion and ethnicity. ${ }^{49}$

Old Irish Catholic devotional systems had been abandoned during penal times in Ireland. In Toronto, as in other centres throughout the New World Irish diaspora, it was replaced by a new system fostered by the work of Alphonsus de Liguori. Devotional exercises were introduced in the Church and taught to family members who could perform them in their homes. To complement those practices, the Church began a program of beautifying its buildings and ceremonies. The overall effect caused an assault upon the mind and the senses which imbued the laity with a peculiar sense of the 'Irish Holy'. Leaving their drab homes and surroundings, the Irish entered an awesome Church were they found peace for a brief interval, respite from the problems of the world, consolation in grief, and pride in accomplishment in their unfriendly and disturbing environment. The Irish sense of the Holy perpetuated the ancient otherworldiness in which there was little distinction between the world of the living and the dead. From it they knew that God was on their side, and through it they were given another view of society, one from eternity, that permeated their Dearcha, their world outlook. ${ }^{50}$ Strengthening the Irish sense of Holy was the concept that the Irish had an historic task to perform - the conversion of North America - a sacred task that could be accomplished if they

\footnotetext{
${ }^{49}$ Nicolson, "The Catholic Church and the Irish in Victorian Toronto", Ph. D. Thesis, University of Guelph, 1981.

${ }^{50}$ From 1869-80, Toronto's Irish newspapers, most particularly the Irish Canadian, printed vivid descriptions of religious services and the laity's response to them which depict the sense of the 'Irish Holy'; Robertson's Landmarks of Toronto, Toronto, 1904, pp. 307-10; R. Otto, Das Heilage, London, 1968.
} 
remained loyal to their Church. The seeds for it had been planted at St. Mary's Church, Clairetown, when the French priests brought out by Charbonnel reminded the Irish of their golden past and how their ancestors had been responsible for the conversion of much of Europe. But the thrust was given impetus by Archbishop Lynch. The improbability of a successful outcome was not questioned. Nonetheless, it gave Irish Catholic culture another reason to preserve itself. ${ }^{51}$

Pilgrimages had been an historic part of life in Ireland. To satisfy that need, Archbishop Lynch created our Lady of Peace Shrine in Niagara as a pilgrimage centre. Toronto's Irish Catholic families packed their lunches, took a boat trip across the lake and spent a pleasant day amid magnificent scenery, but with the objective of fulfilling a religious function. The Redemptorist Fathers established a Shrine to our Mother of Perpetual Help at St. Patrick's Church in the city and obtained control of the pilgrimage Shrine of St. Anne de Beaupré in Quebec, which gave the Toronto Irish access to additional pilgrimage centres. ${ }^{52}$

The importance of the old belief in cures at local shrines and holy wells was modified to a degree in the Canadian setting and Catholicized by the work of Father Francis McSpirrit. That priest, who served in Caledon, Niagara, and Wildfield in the Gore of Toronto, was esteemed as an holy man able to perform miracles and as a strong supporter of temperance. Aware of McSpirrit's popularity as a curer, Archbishop Lynch visited him to ask that he desist from his practices. During their meeting, it seems that Lynch was stricken with a form of paralysis and was unable to rise from his chair. When McSpirrit apparently cured Lynch of that sudden disorder, he was allowed to continue with his work. For a number of years after McSpirrit's death in 1895, Irish Catholics continued to take a handful of earth from his grave with the hope that assistance would be given. On a personal level, Lynch was convinced the age of miracles had not passed. While on pilgrimage to Ireland Lynch had been cured of defective vision after he consumed some plaster at Knock. He was so impressed that he brought to Toronto a considerable amount of the plaster of Knock and censured any priest who spoke of it in a disrespectful manner. Because of its widely

\footnotetext{
${ }^{51}$ ATA, Mission notes, St. Mary's Church, circa 1855; H.C. McKeown, The Life and Labors of the Most Rev. John Joseph Lynch D.D. Cong. Mass. First Archbishop of Toronto, Toronto, 1886, p. 225-6.

52 St. Patrick's Shrine Church Toronto (Toronto, 1974).
} 
acclaimed miraculuous powers Lynch received numerous requests for the plaster from petitioners in Canada and the United States. ${ }^{53}$

For several decades after the Famine migration, a derogatory Irish stereotype and an as equally derogatory papist one were severely upheld in Toronto. Because of that prevailing attitude, some group displacement occurred and there was seepage into the Protestant environment to escape it. The Irish Protestants relinquished their ethnic designation and merged with the general population, for they felt the derision and had as much difficulty dealing with the slogan 'No Irish Apply' as did the Catholics. That left Irish Catholics to contend with the two fused stereotypes which, in reverse effect, strengthened ethnoreligious group solidarity. And as pride developed through accomplishment, Irish Catholics began to resent the generalities of their image as brutal, drunken wife-beaters, ape-like humans in breeches and swallowtail coats, unfit for employment, but capable of doing the bidding of their papist priests - generalities commonly portrayed in the press and on the stage. They never lost the ability to laugh at themselves or to admit their faults but were encouraged not to do it in the presence of outsiders. Evaluation determined future group behaviour to improve the Irish image. The Irish Catholic press promoted a more mature response and gradually the stereotype dissipated. ${ }^{54}$

In fusing the two stereotypes, the Protestant majority of Toronto had pushed the Church into the role of receptacle of Irish culture and the embodiment of the Irish soul, a national institution. The Separate Schools became the nursery of that culture. Within them, staffed by members of their own ethnic group, children were taught religion, academic subjects and pride in nationality. No attempt was made to preserve the Gaelic, for educators realized that English was the language of elitemanship. Irish history was a central focus and school prize nights were opportunities to display pride in Irish Heritage. ${ }^{55}$ There was a proliferation of book stores which sold religious articles and books and supplied a wide variety of Irish literature. All the events in the

\footnotetext{
${ }^{53}$ W. Perkins Bull, From Macdonell to McGuigan, A History of the Roman Catholic Church in Upper Canada, Toronto, 1939. pp. 331-50; ATA, Lynch Papers, Knock file; and L.R. Ward, God in the Irish Kitchen (London) p. 261 .

${ }^{54}$ See the Irish Catholic newspapers for the period 1860-88.

${ }^{55}$ Nicolson, "Irish Catholic Education in Victorian Toronto: An Ethnic Response to Urban Conformity", paper given at Canadian - American Urban Development: A Comparative Urban History Conference, Guelph, 1982.
} 
Catholic community were publicized in the Irish press. Although Irish newspapers had a function in the transfer of the new culture, for most of the period between 1850-90, they were a constant source of division within the Irish community. Their editors spoke out about Irish nationalism and political issues which proved detrimental to group progress in Toronto. As Irish nationalism declined and Irish Tridentine Catholicism increased, the Irish, firmly entrenched in the urban environment, no longer needed an ethnic press. It was replaced with the Catholic Weekly Review and the Canadian Register. For several decades, those journal were patently Irish, but the emphasis was on religion and social issues. ${ }^{56}$

Being an Irish Catholic in Victorian Toronto posed a threat to existence for it meant restricted employment opportunities, denial of civic jobs and exclusion from municipal politics. The Orange Order controlled the city and Irish Catholics had little social mobility. To shut out abuse, a form of ethno-religious privatism developed. Living either in a physical ghetto of Irish concentration, or isolated in Protestant areas, Irish Catholics carried their culture into the workplace where they performed their tasks in solitude and departed. They never discussed religion or politics for fear of riot, nor did they interact socially with Protestant workers who ridiculed them. They had little in common with those outside their group and privatism dictated that one was born into it; marrying outside of it meant rejection of both religion and ethnicity. In areas where there were few of their kind, that privatism was more severe, for there Irish Catholics lived in a mental ghetto which did not extend beyond the confines of their homes. However, they participated in the social activities of the physical ghetto where the Church was the focus of their lives. ${ }^{57}$

Born in the ghettos of Toronto, Irish Tridentine Catholicism, an urban-based culture, was spread through the parish networks to become the standard minority culture in English-speaking Ontario. Its vehicles were the Church's communication system, ${ }^{58}$ the separate schools, the

\footnotetext{
${ }^{56}$ Nicolson, "The Catholic Church and the Irish".

${ }^{57}$ Nicolson, "Six Days Shalt Thou Labour".

${ }^{58}$ Nicolson. "Ecclesiastical Metropolitanism and the Evolution of the Archdiocese of Toronto", Social History, vol. XV, no. 29, May 1982, pp. 129-56.
} 
religious orders of nuns and priests, the Irish press, the St. Vincent de Paul Society and the kinship patterns of the people. The culture was born from the need of a peasantry to survive in the commercial metropolis of Toronto and the Church's need to retain that group as its laity. Certainly the vast number of elements within the new culture were religious; only a minority were of Irish peasant origin. However, religious elements were reinterpreted and looked upon in an Irish fashion. As the Irish in Ontario became Tridentine Catholics, the Church became Irish in the Victorian era. 